\title{
Hyperdibasic aminoaciduria type 1
}

INSERM

\section{Source}

INSERM. (1999). Orphanet: an online rare disease and orphan drug data base.

Hyperdibasic aminoaciduria type 1. ORPHA:1032

Hyperdibasic aminoaciduria, type 1 is characterised by increased renal clearance of lysine, ornithine and arginine, in the presence of normal concentrations of cystine.

Heterozygous individuals are asymptomatic but homozygotes display intellectual deficit.

To date, 25 heterozygotes and one homozygote have been reported. 